\title{
Immunotherapeutic approach to nasopharyngeal cancer
}

\author{
Timothy Allen ${ }^{1 *}$, Abdullateef Al-Hadeethi ${ }^{2}$ and Ghazaleh Shoja E Razavi ${ }^{3}$ \\ ${ }^{1}$ Global Allied Pharmaceutical, Center for Excellence in Research \& Development, USA \\ ${ }^{2}$ Associate editor, Global Allied Pharmaceuticals, Jordan \\ ${ }^{3}$ Director, Clinical Development- Oncology and Respiratory, Global Allied Pharmaceutical, USA
}

\begin{abstract}
Nasopharyngeal cancer (NPC) is a rare cancer in most populations like the Caucasians in North America; it is a leading form of cancer in a few well-defined populations, including natives of southern China, Southeast Asia, the Arctic, and the Middle East/North Africa. The distinctive racial/ethnic and geographic distribution of NPC worldwide suggests that both environmental factors and genetic traits contribute to its development. In this review we aim to discuss the pathophysiology of NPC and the active molecules involved in immunotherapy.
\end{abstract}

\begin{abstract}
Abbreviations
NPC: Nasopharyngeal Cancer; EBV: Ebstein-Barr Virus; HNSCC: Head and Neck Squamous Cell Carcinoma; HPV: Human Papilloma Virus; Rb: Retinoblastoma; EGFR: Epidermal Growth Factor Receptor; DBD: DNA Binding Domain; RTK: Receptor Tyrosine Kinase; CTL: Cytotoxic T Lymphocyte; TA: Trojan Antigen; APC: Antigen Presenting Cells; TGN: Trans-Golgi Network.

\section{Introduction/epidemiology}

Nasopharyngeal carcinoma (NPC) is a squamous cell carcinoma with remarkable geographic and racial distribution worldwide. It is a rare malignancy with an incidence below $1 / 100,000$ populations per year in Caucasians from North America and other Western countries. In contrast, the highest incidence is noted in the Southern Chinese population of Guangdong, Inuits of Alaska, and native Greenlanders and particularly, among the Cantonese who inhabit the central region of Guangdong Province in Southern China where the incidence is 1525 cases per 100,000 [1].

Swelling of the lymph nodes in the neck is the initial presentation in many people, and the diagnosis of NPC is often made by lymph node biopsy. Signs and symptoms related to the primary tumor include trismus, pain, otitis media, nasal regurgitation due to paresis (loss of or impaired movement) of the soft palate, hearing loss and cranial nerve palsy. Larger growths may produce nasal obstruction or bleeding and a "nasal twang". Metastatic spread may result in bone pain or organ dysfunction. Rarely, a paraneoplastic syndrome of osteoarthropathy may occur with widespread disease [2].
\end{abstract}

\section{Etiology and pathogenesis}

In endemic regions, NPC presents as a complex disease believed to be caused by an interaction between an oncogenic EBV-induced chronic infection, environmental, and genetic factors, in a multistep carcinogenic process [2]. The highest incidence of NPC in Southern Chinese strongly indicates that both genetic susceptibility and environmental factors contribute to the tumorigenesis of NPC related to its development and progression. Viral etiologies as well as other environmental and life-style factors have been proposed as causative components of NPC.

\section{Epstein-Barr virus (EBV)}

The EBV infects and persists latently in over $90 \%$ of the world population [3]. Although primary EBV infection is typically subclinical, the virus is associated later with the development of several malignancies, including NPC [4]. Transmission, mainly through saliva, occurs earlier in life in developing countries, where living conditions are crowded and less hygienic. B lymphocytes are the primary target of EBV infection, although the route of EBV entry into epithelial cells is unclear; nevertheless, EBV replication can occur in oropharyngeal epithelial cells, as well as in B lymphocytes in both normal and malignant nasopharyngeal tissue [5].

The involvement of EBV in NPC has been postulated since 1966, when NPC patients were found to express antibodies against an antigen later identified as belonging to EBV [6]. This finding was confirmed in 1970, when anti-EBV antibodies were observed to be higher in NPC patients than in controls [7]. Subsequent studies showed that NPC patients had elevated titers of IgG and IgA antibodies to the EBV viral capsid antigen $\lg \mathrm{A}$ and early antigen, as well as increased $\operatorname{IgG}$ titers against the latent viral nuclear antigens 1 and 2 (EBNA-1, EBNA2) and neutralizing antibodies against EBV-specific DNase $[8,9]$. Moreover, these antibody titers, especially of IgA, preceded tumor development by several years and were correlated with tumor burden, remission, and recurrence. Based on these patterns, antibody against viral capsid antigen is now established as the basis of a screening test for NPC in high-risk populations, particularly in combination with anti-EBV DNase antibodies. More recently, circulating cell-free EBV

Correspondence to: Dr. Timothy Allen, MD, Ph.D., Global Allied Pharmaceutical, Center for Excellence in Research and Development, 160 Vista Oak Dr. Longwood, FL 32779, USA, Tel: 1-321-945-4283, E-mail: timothy.allen@gapsos.com

Key words: EBV, NPC, immunotherapy, epidermal growth factor receptor, kinase inhibitor, monoclonal antibody, cytokine, vaccine, $T$ cell

Received: April 20, 2016; Accepted: May 24, 2016; Published: May 27, 2016 
DNA has been detected in a higher proportion of NPC patients than controls, and these levels were positively correlated with disease stage and prognosis, although prospective studies of pre-disease levels have yet to be performed [10-15].

Considerable research has been directed toward determining whether at least part of the international pattern in the incidence of NPC can be explained by the distribution of different EBV strains. Compared with the prototype B95.8 EBV strain, consistent nucleotide variation in the amino terminus of the oncogenic viral latent membrane protein 1 (LMP1), including the loss of a XhoI restriction site, has been detected in EBV in NPC tumors from southern and northern Chinese, Malaysians, Alaska natives, and some U.S. Caucasians, but not North Africans. Other types of sequence variations in the LMP1 carboxyl terminus-including the number of copies of a 33-bp repeat element, a 15-bp insertion in the third repeat element, and a 30-bp deletion in the carboxyl terminus-have repeatedly been detected in Chinese NPC tumors [16-21]. The 30-bp deletion, also detected in a proportion of native Alaskans, Caucasian, Malaysian, and North African NPC, seems to enhance the transforming potential of LMP1 in vitro, and may be present in more aggressive disease forms. However, there is no strong evidence that the deleted variant is associated with increased risk of NPC, and there is a lack of large, well-designed epidemiologic studies of risk associations with EBV variants. Furthermore, the detection of specific LMP1 mutations in NPC tumors from diverse regions suggests that EBV strain variation is not geographically correlated with NPC incidence. Alternatively, the predominance of specific LMP1 variants in NPC could be influenced by immune selection, as certain key LMP1 mutations may produce a reduced cytotoxic $\mathrm{T}$ lymphocyte (CTL) response [22].

\section{Salt-preserved fish and other foods}

The non-viral exposure most consistently and strongly associated with the risk of developing NPC is consumption of salt-preserved fish, a traditional staple food in several NPC-endemic areas. In studies of Chinese populations, the relative risk of NPC associated with weekly consumption of salt-preserved fish, compared with no or rare consumption, generally ranged from 1.4 to 3.2 , whereas that for daily consumption of salt-preserved fish ranged from 1.8 to 7.5 [23].

\section{Tobacco and other smoke}

The majority of case-control studies examining cigarette smoking and risk of NPC in a variety of populations reported an increased risk of 2- to 6-fold. In two studies from China, NPC cases were up to 5-fold more likely to have been exposed to domestic wood fire than controls [24], but other studies found no such association [25,26].

\section{Human leukocyte antigen genes}

Searching for genes conferring susceptibility to NPC has focused on the human leukocyte antigen (HLA) genes. These genes encode proteins required for the presentation of foreign antigens, including the presentation of viral peptides to the immune system for targeted tumor cell death. For example, because virtually all NPC tumors contain EBV, individuals who inherit HLA alleles with a reduced ability to present EBV antigens may have an increased risk of developing NPC, whereas individuals with HLA alleles that present EBV efficiently may have a lower risk.

Some HLA alleles have been consistently associated with NPC risk. Thus, in southern Chinese and other Asian populations, HLA-A2-B46 and B17 were generally associated with a 2- to 3 -fold increase in NPC risk [27-29]. In contrast, a 30\%-50\% lower risk of NPC was found in association with HLA-A11 in both Chinese and Caucasians, B13 in Chinese, and A2 in Caucasians. In a meta-analysis of studies performed in southern Chinese populations, the combined evidence suggested a positive association of NPC risk with HLA-A2, B14, and B46, and an inverse association with HLA-A11, B13, and B22. In a linkage study, a gene closely linked to the HLA locus conferred a 21-fold excess risk for developing NPC; a separate study mapped an NPC susceptibility locus to a region near HLA-A. However, the reported associations between NPC risk and other HLA genes, including class II alleles, must be interpreted with caution due to the probability of chance findings based on multiple comparisons [30-32].

\section{Immunotherapy for nasopharyngeal cancer}

\section{Kinase inhibitor drugs}

There are no kinase inhibitors which are currently approved by FDA for NPC. However, a few drugs are in phase I-III clinical trials as shown in Table 1.

Erlotinib: Erlotinib is an aquinazoline derivative with antineoplastic properties. Erlotinib, acting as an adenosine triphosphate competitor reversibly binds to the intracellular catalytic domain of epidermal growth factor receptor (EGFR) tyrosine kinase, thereby reversibly inhibiting EGFR phosphorylation and blocking the signal transduction events and tumorigenic effects associated with EGFR activation.

\section{Checkpoint inhibitor drugs}

A few of this class of drugs are under clinical trials in phases I, II, and III as in Table 2 below.

Nivolumab: Nivolumab is a fully human monoclonal antibody directed against the negative immunoregulatory human cell surface receptor PD-1 (programmed death-1 or programmed cell death-1/ PCD-1) with immunopotentiation activity. Nivolumab binds to and blocks the activation of PD-1, an Ig superfamily transmembrane protein, through its ligands $\mathrm{PD}-\mathrm{L} 1$ and $\mathrm{PD}-\mathrm{L} 2$, resulting in the activation of T-cells and cell-mediated immune responses against tumor cells or pathogens. Activated PD-1 negatively regulates T-cell activation and effector functions through the suppression of P13K/Akt pathway activation [34].

\section{Vaccine therapy}

Although there are no vaccines which are currently approved by FDA for NPC, few vaccine formulations are in phase I clinical trials as shown in Table 3.

Mutant 553 peptide, pulsed dendritic cell vaccine: This is an anticancer vaccine, consisting of autologous dendritic cells, which have been pulsed with a mutant $\mathrm{p} 53$ peptide. The premise is that many tumor

\begin{tabular}{|c|c|c|c|c|}
\hline Drug & $\begin{array}{c}\text { Clinical trial identifier } \\
\text { number }\end{array}$ & Phase & Study design & Target \\
\hline Erlotinib & NCT01316757 & Phase II & $\begin{array}{c}\text { Open label, Efficacy } \\
\text { Study }\end{array}$ & EGFR \\
\hline
\end{tabular}

Table 1. Non-FDA approved kinase inhibitor drugs [33].

\begin{tabular}{|c|c|c|c|c|}
\hline Drug & $\begin{array}{c}\text { Clinical trial identifier } \\
\text { number }\end{array}$ & Phase & Study design & Target \\
\hline Nivolumab & NCT02339558 & Phase II & $\begin{array}{c}\text { Efficacy Study, Open } \\
\text { Label }\end{array}$ & PD-1 \\
\hline
\end{tabular}

Table 2. Non-FDA approved check point inhibitor drugs [34]. 
Table 3. Non-FDA approved vaccines [35]

\begin{tabular}{|c|c|c|c|}
\hline Drug & Clinical trial identifier number & Phase & Study design \\
\hline Mutant p53 peptide pulsed dendritic cell vaccine & NCT00404339 & Phase I & Randomized \\
\hline MAGE-A3 HPV-16 vaccine & NCT00704041 & Phase I & Randomized, Open Label, Safety/Efficacy Study, \\
\hline
\end{tabular}

cells overexpress mutant $\mathrm{p} 53$ proteins, resulting in the loss of apoptosis regulation and abnormal cell proliferation. Therefore, vaccination with mutant p53 peptide pulsed dendritic cells may stimulate the host immune system to mount a CTL response against tumor cells expressing mutant $\mathrm{p} 53$, resulting in tumor cell lysis.

MAGE-A3 HPV-16 vaccine: This is a multi-epitope "Trojan Antigen"- ("TA") construct vaccine with immunostimulatory and anti-tumor activities. It consists of human melanoma antigen A3 (MAGE-A3) and human papillomavirus (HPV) 16 peptide epitopes, which are linked by the furin-sensitive linker peptide, RVKR (arginineserine-lysine-arginine). The TA-construct enters the cytoplasm of antigen-presenting cells (APCs) where it is processed in the endoplasmic reticulum (ER) and the trans-Golgi network (TGN), by the endopeptidase, furin. This process releases the epitopes from the RVKR linker peptide and, together with various exopeptidases, generates MHC class I-binding peptides. Expressed on the cell surfaces of APCs, these MHC class I-binding peptides stimulate a cytotoxic T lymphocyte (CTL) response against tumor cells that display the same peptide epitopes on their cell surfaces.

\section{Conclusions and future perspectives}

Ongoing research activities have increased our understanding of the tumor microenvironment, various immunotherapeutic modalities and combination therapies (i.e., combining chemotherapy with immunotherapy). However, the effects of such modalities in combination with chemotherapy in cancer patients are still in the exploratory phase. Moreover, the complete perspective of immunotherapy treatment has not been realized and/or utilized. Proper pre-clinical and clinical designs are the important pillars for understanding the future of immunotherapy in treating cancer patients.

\section{References}

1. Chou J, Lin YC, Kim J, You L, Xu Z, et al. (2008) Nasopharyngeal carcinoma--review of the molecular mechanisms of tumorigenesis. Head Neck 30: 946-963. [Crossref]

2. Reiter S, Gavish A, Winocur E, Emodi-Perlman A, Eli I (2006) Nasopharyngeal carcinoma mimicking a temporomandibular disorder: a case report. J Orofac Pain 20: 74-81. [Crossref]

3. Rickinson AB, Kieff E. (2001) Epstein-Barr virus. In: Knipe DM, Howley PM, editors. Field's virology. (edn. 4th) Lippincott, Williams \& Wilkins, USA pp. 2575-2627.

4. 4. IARC. IARC monographs on the evaluation of carcinogenic risks to humans. (1997) Volume 70: Epstein-Barr virus and Kaposi's herpesvirus/human herpesvirus 8. Lyon: IARC Press.

5. Chen CL, Hsu MM, Hsu HC (1996) Differential expression of EBER1 in nontumor nasopharyngeal biopsies and nontumor component of nasopharyngeal carcinoma. Intervirology 39: 230-235. [Crossref]

6. Old LJ, Boyse EA, Oettgen HF, Harven ED, Geering G, et al. (1966) Precipitating antibody in human serum to an antigen present in cultured burkitt's lymphoma cells. Proc Natl Acad Sci US A 56: 1699-1704. [Crossref]

7. Henle W, Henle G, Ho HC, Burtin P, Cachin Y, et al. (1970) Antibodies to EpsteinBarr virus in nasopharyngeal carcinoma, other head and neck neoplasms, and control groups. J Natl Cancer Inst 44: 225-231. [Crossref]

8. Sawaki S, Sugano H, Hirayama T, Kawamura A Jr, Tachibana T (1975) Histopathological and immunological studies of nasopharyngeal carcinoma. Zhonghua Min Guo Wei Sheng Wu Xue Za Zhi 8: 73-81. [Crossref]

9. Zheng X, Yan L, Nilsson B, Eklund G, Drettner B (1994) Epstein-Barr virus infection, salted fish and nasopharyngeal carcinoma. A case-control study in southern China. Acta Oncol 33: 867-872. [Crossref]

10. Mutirangura A, Pornthanakasem W, Theamboonlers A, Sriuranpong V, Lertsanguansinchi P, et al. (1998) Epstein-Barr viral DNA in serum of patients with nasopharyngeal carcinoma. Clin Cancer Res 4: 665-669. [Crossref]

11. Lo YM, Chan LY, Lo KW, Leung SF, Zhang J, et al. (1999) Quantitative analysis of cell-free Epstein-Barr virus DNA in plasma of patients with nasopharyngeal carcinoma. Cancer Res 59: 1188-1191. [Crossref]

12. Lin JC, Chen KY, Wang WY, Jan JS, Liang WM, et al. (2001) Detection of Epstein-Bar virus DNA in the peripheral-blood cells of patients with nasopharyngeal carcinoma: relationship to distant metastasis and survival. J Clin Oncol 19: 2607-2615. [Crossref]

13. Lin JC, Wang WY, Chen KY, Wei YH, Liang WM, et al. (2004) Quantification of plasma Epstein-Barr virus DNA in patients with advanced nasopharyngeal carcinoma. N Engl J Med 350: 2461-2470. [Crossref]

14. Nawroz H, Koch W, Anker P, Stroun M, Sidransky D (1996) Microsatellite alterations in serum DNA of head and neck cancer patients. Nat Med 2: 1035-1037. [Crossref]

15. Chan AT, Lo YM, Zee B, Chan LY, Ma BB, et al. (2002) Plasma Epstein-Barr virus DNA and residual disease after radiotherapy for undifferentiated nasopharyngeal carcinoma. J Natl Cancer Inst 94: 1614-1619. [Crossref]

16. Miller WE, Edwards RH, Walling DM, Raab-Traub N (1994) Sequence variation in the Epstein-Barr virus latent membrane protein 1. J Gen Virol $75: 2729-2740$. [Crossref]

17. Edwards RH, Seillier-Moiseiwitsch F, Raab-Traub N (1999) Signature amino acid changes in latent membrane protein 1 distinguish Epstein-Barr virus strains. Virology 261: 79-95. [Crossref]

18. Sung NS, Edwards RH, Seillier-Moiseiwitsch F, Perkins AG, Zeng Y, et al. (1998) Epstein-Barr virus strain variation in nasopharyngeal carcinoma from the endemic and non-endemic regions of China. Int J Cancer 76: 207-215. [Crossref]

19. Tan EL, Peh SC, Sam CK (2003) Analyses of Epstein-Barr virus latent membrane protein-1 in Malaysian nasopharyngeal carcinoma: high prevalence of 30-bp deletion, Xho1 polymorphism and evidence of dual infections. J Med Virol 69: 251-257. [Crossref]

20. Cheung ST, Lo KW, Leung SF, Chan WY, Choi PH, et al. (1996) Prevalence of LMP1 deletion variant of Epstein-Barr virus in nasopharyngeal carcinoma and gastric tumors in Hong Kong. Int J Cancer 66: 711-712. [Crossref]

21. Cheung ST, Leung SF, Lo KW, Chiu KW, Tam JS, et al. (1998) Specific latent membrane protein 1 gene sequences in type 1 and type 2 Epstein-Barr virus from nasopharyngeal carcinoma in Hong Kong. Int J Cancer 76: 399-406. [Crossref]

22. Edwards RH, Sitki-Green D, Moore DT, Raab-Traub N (2004) Potential selection of LMP1 variants in nasopharyngeal carcinoma. J Virol 78: 868-881. [Crossref]

23. Henderson BE, Louie E (1978) Discussion of risk factors for nasopharyngeal carcinoma. IARC Sci Publ: 251-260. [Crossref]

24. Vaughan TL, Shapiro JA, Burt RD, Swanson GM, Berwick M, et al. (1996) Nasopharyngeal cancer in a low-risk population: defining risk factors by histological type. Cancer Epidemiol Biomarkers Prev 5: 587-593. [Crossref]

25. Lanier A, Bender T, Talbot M, Wilmeth S, Tschopp C, et al. (1980) Nasopharyngeal carcinoma in Alaskan Eskimos Indians, and Aleuts: a review of cases and study of Epstein-Barr virus, HLA, and environmental risk factors. Cancer 46: 2100-2106. [Crossref]

26. Lin TM, Chen KP, Lin CC, Hsu MM, Tu SM, et al. (1973) Retrospective study on nasopharyngeal carcinoma. J Natl Cancer Inst 51: 1403-1408. [Crossref]

27. Zhang F, Zhang J (1999) Clinical hereditary characteristics in nasopharyngeal carcinoma through Ye-Liang's family cluster. Chin Med J (Engl) 112: 185-187. [Crossref]

28. Simons MJ, Chan SH, Wee GB, Shanmugaratnam K, Goh EH, et al. (1978) Nasopharyngeal carcinoma and histocompatibility antigens. IARC Sci Publ: 271-282. [Crossref] 
29. Chan SH, Day NE, Kunaratnam N, Chia KB, Simons MJ (1983) HLA and nasopharyngeal carcinoma in Chinese--a further study. Int $J$ Cancer 32: 171-176. [Crossref]

30. Goldsmith DB1, West TM, Morton R (2002) HLA associations with nasopharyngeal carcinoma in Southern Chinese: a meta-analysis. Clin Otolaryngol Allied Sci 27: 6167. [Crossref]

31. Lu SJ, Day NE, Degos L, Lepage B, Wang PC, et al. (1990) Linkage of a nasopharyngeal carcinoma susceptibility locus to the HLA region. Nature 346: 470-471. [Crossref]

32. Lu CC, Chen JC, Tsai ST, Jin YT, Tsai JC, et al. (2005) Nasopharyngeal carcinoma- susceptibility locus is localized to a $132 \mathrm{~kb}$ segment containing HLA-A using highresolution microsatellite mapping. Int J Cance. 115: 742-746. [Crossref]

33. National Cancer Institute (NCI); National Cancer Institute (NCI).Nivolumab in Treating Patients with Recurrent and/or Metastatic Nasopharyngeal Cancer. In: ClinicalTrials. gov [Internet]. Bethesda (MD): National Library of Medicine (US). 2015; April 24.

34. University of Pittsburgh; National Cancer Institute (NCI).Vaccine Therapy in Treating Patients with Head and Neck Cancer. In: ClinicalTrials.gov [Internet]. Bethesda (MD) National Library of Medicine (US). 2015; April 24

35. University of Maryland; University of Maryland. University of Maryland. University of Maryland. In: ClinicalTrials.gov [Internet]. Bethesda (MD): National Library of Medicine (US). 2015; April 24.

Copyright: (C2016 Allen T. This is an open-access article distributed under the terms of the Creative Commons Attribution License, which permits unrestricted use, distribution, and reproduction in any medium, provided the original author and source are credited. 